\title{
Moderating Effect of the 2001-65 Law Relating to Credit Tunisian Institutions on Discretionary Practices
}

\author{
Amina Zgarni ${ }^{1} \&$ Hassouna Fedhila ${ }^{2}$ \\ ${ }^{1}$ Faculty of Economic Sciences and Management of Tunis, University of Tunis El Manar, Tunisia \\ ${ }^{2}$ American University in North Africa Business School, Tunisia \\ Correspondence: Amina Zgarni, Faculty of Economic Sciences and Management of Tunis, Tunisia. E-mail: \\ amina2302@yahoo.fr
}

Received: December 10, 2020

Accepted: December 21, 2020

Online Published: January 22, 2021

doi:10.5539/ass.v17n2p54

URL: https://doi.org/10.5539/ass.v17n2p54

\begin{abstract}
The multitude of financial scandals throughout the last two decades is mainly due to fraud and significant irregularities recorded in the financial statements published following accounting manipulations. The aim of this study is to test the moderating effect of Law 2001-65 relating to credit institutions on discretionary practices within Tunisian banks. Following a comparative study of discretionary practices before the introduction of this law and after its introduction, on a sample of Tunisian commercial banks we have shown the crucial role played by this law in the limitation of discretionary behavior in order to align regulatory capital in relation to the period preceding the promulgation of this law (1990-2000). However, we have shown an increase in these discretionary behaviors for earnings management purposes during the period following the entry into force of this law (2001-2019)
\end{abstract}

Keywords: Earnings management, Tunisian banks, Abnormal provisions

\section{Introduction}

The multitude of financial scandals throughout the last two decades is mainly due to fraud and significant irregularities recorded in the financial statements published following accounting manipulations. In fact, managers can modify certain elements of financial and accounting documents for the purpose of earnings management and / or capital management or for their opportunistic objectives. This is all the more adopted, in particular, when the remuneration is based on the financial performance achieved or to avoid the possible troubles that may arise in the debt market following the surprise linked to the publication of a bad result. In this regard, the banking context constitutes a highly favorable ground for earnings management practices. Among the techniques of earnings management practices most commonly used in banks, there are specific accruals, which include loan loss provisions.

To do this, various laws have emerged around the world to restore the confidence of financial markets. In this case, in the USA, the Sarbanes-Oxley Act of 2002 (SOX), promulgated in particular following the Enron affair, and which had the main objective of protecting investors by improving the accuracy and reliability of the information disclosure. Consequently, various American studies have begun to compare measures of the quality of the earnings before and after SOX, and the majority report evidence suggesting the improvement of the quality of the earnings after SOX (DeZoort et al., 2008; Cohen et al., 2010). In the European context, the entry into force of the decree of December 8, 2008, rectifying the 8th directive of the European Parliament (EP) and of the Council of the European Union (CUE) relating to the statutory audit of accounts, has strengthened certain governance mechanisms to improve the quality of financial information. Studies to show the effectiveness of this law in limiting earnings management practices are proving controversial. In Tunisia, in order to strengthen the transparency of financial information disclosed by companies and in particular by banks, important standards have been put in place by the Tunisian public authorities. The implementation of Law 2001-65 is an important step towards achieving these objectives. This law imposed, among other things, certain governance mechanisms and the conditions for their effectiveness and set regulatory capital thresholds inspired by the Basel agreement of 1988. The purpose of this study is to examine the possible moderating effect of the adoption of Law 2001-65 on the likelihood of reduced earnings management in the Tunisian banking context. 


\section{Literature Review and Hypothesis Development}

Based on the literature review, we found that earnings management in banks is done through the adjustment of accruals accounts including, in particular, loan loss provisions. However, two essential factors that may influence these provisions which are the most studied in the literature, namely: regulatory capital and earnings before tax and provisions

- The impact of earnings before taxes and provisions on abnormal provisions:

Provisions may be deliberately underestimated to mitigate the adverse effect of other factors on earnings in the event of poor performance, or overestimated in the event of good performance in order to reduce earnings variability. Abou El Sood (2012) has shown that well-performing banks overestimate their loan loss provisions in order to build up reserves for future periods. Lobo and Yang (2001) find that managers of banks with high return variability are more inclined to smooth out earnings through loan loss provisions. Studies testing the effect of pre-tax income and provisions on abnormal provisions in banks show controversial results. In this sense, Ahmed et al (1999) found a positive relationship on a sample of American banks. Kwak et al. (2009) found a negative relationship on a sample of Japanese banks. While Zgarni an Fedhila (2019) found no significant relationship between these two variables on a sample of Tunisian banks. In this work, we propose that this relation will be either stronger during the period preceding the promulgation of the law 2001-65 or the period (1990-2000) and less strong during the period which follows it (2001-2019).

Thus, we make the following hypothesis:

H-1: The effect of earnings (before taxes and loan loss provisions) on abnormal provisions will be weaker in Tunisian commercial banks after the imposition of Law 2001-65 than before its imposition.

- The impact of the capital ratio on abnormal provisions

An analysis of the accounting literature shows that studies on the effect of the capital ratio on abnormal provisions, including those by Moyer (1990) and Beatty et al. (1995), have shown that managers manipulate their provisions to reach capital regulatory. This in particular when loan loss provisions are part of the numerator of the capital ratio in the period before the 1988 Basel Accord.On the other hand, in the period after this accord, this relationship becomes less important (Ahmed et al., 1999). in fact, in different contexts, studies on the relationship between the capital ratio and abnormal provisions are divergent. Some studies have shown that this relationship is negative, in particular those of Ahmed et al. (1999), Boudriga et al. (2009), Zgarni and Fedhila (2019). While Cornett et al. (2006), among others, found this relationship to be positive. However, Leventis et al. (2011) found no relation between regulatory capital and abnormal provisions. In this study, we therefore expect that this relation will be stronger in the period preceding the entry into force of this law (1990-2000) and less strong during the period following it (2001-2019). Thus, we make the following hypothesis

H-2: The effect of the capital ratio on abnormal provisions will be weaker in Tunisian commercial banks after the imposition of Law 2001-65 than before its imposition.

\section{Research Methodology}

\subsection{Sample and Study Period}

Our sample is made up of the main Tunisian banks. Since we plan to test the moderating effect of the implementation of Law 2001-65 on results management practices, we then studied this relationship for two different periods; the first runs from 1990 to 2000 (before the introduction of Law 2001-65 on credit institutions) and the second runs from 2001 to 2019 (after the introduction of this law)."

These two models will be estimated over two different periods, the first preceding the promulgation of the law 2001-65 (1990-2000) while the second succeeds it (2001-2019).

\subsection{Measurement of Variables and Models to Be Estimated}

Like Kanagaretnam et al. (2010), we estimated our first model in order to identify the abnormal provisions (ALLP) which correspond to the residuals of the model and which will be used as dependent variable in the second model.

The first model to estimate is as follows:

$$
L L P_{i t}=\beta_{0}+\beta_{1} N P L_{i t}-1+\beta_{2} \text { CHNPL }_{i t}+\beta_{3} \text { CHLOAN }_{i t}+\varepsilon_{i t}
$$

The residual of this first estimate corresponds to the abnormal provisions which will be used as dependent variable in the second model. 


$$
\varepsilon_{\mathrm{i}}=A L L P_{i t}=\beta_{0}+\beta_{1} E B T P_{i t}+\beta_{2} C A R_{i t}+\beta_{3} L A S S E T_{i t}+\beta_{4} R O A_{i t}+\varepsilon_{i t}
$$

Table 1 . Summary table of variables and measures used in the study

\begin{tabular}{|c|c|c|}
\hline \multicolumn{3}{|r|}{ DEPENDENT VARIABLES } \\
\hline \multirow[t]{2}{*}{ Variables } & \multicolumn{2}{|r|}{ DEPENDENT VARIABLES } \\
\hline & \multicolumn{2}{|r|}{ Definitions and measures } \\
\hline LLPi & \multicolumn{2}{|r|}{ Allocations for loan loss provisions of bank i } \\
\hline \multirow[t]{3}{*}{$\operatorname{ALLP}_{\text {it }}$} & \multicolumn{2}{|r|}{ Abnormal loan loss provisions of bank $\mathrm{i}$ at date $\mathrm{t}$} \\
\hline & \multicolumn{2}{|r|}{ INDEPENDENT VARIABLES } \\
\hline & \multicolumn{2}{|r|}{ Definitions and measures } \\
\hline \multirow{5}{*}{$\begin{array}{l}\text { Variables linked to } \\
\text { earnings management }\end{array}$} & $\mathrm{NPL}_{\mathrm{it}-1}$ & Initial balance of non-performing loans of bank $i$ at date $t$ \\
\hline & CHNPL $_{\text {it }}$ & change in non-performing loans between $t$ and $t-1$ of bank $i$ at date $t$ \\
\hline & CHTLOAN $_{\text {it }}$ & change in total loans from bank $\mathrm{i}$ at date $\mathrm{t}$ \\
\hline & $\mathrm{EBTP}_{\text {it }}$ & $\begin{array}{l}\text { This variable is measured by earnings before tax and provision which is } \\
\text { calculated from the income statement (it is equal to gross operating income } \\
\text { less provisions) }\end{array}$ \\
\hline & $\mathrm{CAR}_{\text {it }}$ & Capital ratio. (total equity divided by total bank assets) \\
\hline \multirow{2}{*}{ control variables } & LASSET $_{\text {it }}$ & $\begin{array}{l}\text { Size of the bank, it is measured by the natural logarithm of the total assets of } \\
\text { the bank }\end{array}$ \\
\hline & $\mathrm{ROA}_{\mathrm{it}}$ & $\begin{array}{l}\text { Return on assets: this variable corresponds to the assessment of return on } \\
\text { assets. (It is measured by: Net income / total assets) }\end{array}$ \\
\hline
\end{tabular}

\section{Results and Discussion}

\subsection{Estimation of Abnormal Provisions (1990-2000)}

A/ Summary Statistics (1990-2000):

The Summary Statistics of variables used under the period 1990-2000 are presented in the table below:

Table 2. Summary Statistics (1990-2000)

\begin{tabular}{ccccc}
\hline Variable & EBTP & CAR & LASSET & ROA \\
\hline Moyenne & .0279737 & .2382603 & 13.96862 & .0086941 \\
Min & .0063566 & .033942 & 12.62887 & .0000607 \\
Max & .0683691 & .3331156 & 15.155 & .0517559 \\
Ecart type & .0158117 & .1460926 & .5302621 & .0054496 \\
Observation & 110 & 110 & 110 & 110 \\
\hline
\end{tabular}

According to the table of descriptive statistics above, the variable "EBTP" is 2, 79\% on average with a minimum of $0.63 \%$ and a maximum of $6.83 \%$. These findings are similar to taktak and mbarki (2014) in their study on a sample of Tunisian banks over the period from 2003 to 2007. they found an average value of ebtp equal to $1.7 \%$. The standard deviation is $1.58 \%$ indicating a very low volatility of this variable in our sample. Concerning the variable "CAR", it shows an average of $23,82 \%$ and varies between a minimum of 3,39\% and a maximum of $33,31 \%$. So, we can say that the tnisian banks in our sample are largely capitalized. The standard deviation is $14,60 \%$, indicating a fairly average volatility of this variable in our sample.

Regarding the control variables, the variable "LASSET" is 13.96. with a minimum of 12,62 and a maximum of 15,15 . the standard deviation is $53.02 \%$ indicating high volatility in our sample. Finally, the variable "ROA" shows an average of $0.86 \%$, a minimum of $-0,006 \%$, a maximum of $5,17 \%$ and a standard deviation of $0.54 \%$.

B/ model regression results (1990-2000)

The Table 3 below presented the regression results carried out on our sample of 10 Tunisian commercial banks during the period from 1990 to 2000 (110 observations)

Table 3. Model regression results during the period 1990-2000

$\begin{array}{llllll}\text { Variable } & \text { Coefficient. } & \text { Std. Err } & \mathrm{z} & \mathrm{P}>\mid \mathrm{z} & \text { [95\% Conf. Interval] }\end{array}$




\begin{tabular}{ccccccc}
\hline EBTP & .0462198 & .0908043 & 0.51 & 0.611 & -.1317533 & .224193 \\
CAR & -.0408777 & .0092982 & -4.40 & $0.000^{* * *}$ & -.0591019 & -.0226535 \\
ROA & .2243253 & .2476507 & 0.91 & 0.365 & -.2610612 & .7097118 \\
LASSET & -.0145305 & .0027311 & -5.32 & $0.000^{* * *}$ & -.0198835 & -.0091776 \\
Constante & .2094678 & .0396519 & 5.28 & 0.000 & .1317516 & .287184 \\
\hline
\end{tabular}

$* * *$ Significant at $1 \%, * *$ Significant at $5 \%$ and $*$ Significant at $10 \%$

From this table, it turns out that the effect of the variable (EBTP) on abnormal provisions is not significant. This result corroborates that of Fernando and Ekanayake (2015) who proved that banks do not manage their earnings via loan loss provisions. These authors found an insignificant relation between EBTP and abnormal provisions in their sample of commercial banks in Sri Lanka. However, concerning the "capital ratio (CAR)" variable, our results indicate a negative effect on abnormal provisions at the 5\% threshold. This shows that the managers of banks are heavily manipulating their provisions for the purposes of capital management. Our findings are comparable to that of Kwak et al (2009).

\subsection{Estimate of Abnormal Provisions (2001-2019)}

A/. Summary Statistics:

Summary Statistics of variables under the period 2001-2019 are presented in Table 4 below:

Table 4. Summary Statistics (2001-2019)

\begin{tabular}{|ccccc|}
\hline Variable & $\mathbf{E B T P}_{\text {it }}$ & $\mathbf{C A R}_{\mathbf{i t}}$ & LASSET $_{\mathbf{i t}}$ & ROA $_{\mathbf{i t}}$ \\
\hline Mean & .0233786 & .10112344 & 15.18131 & 0,00864706 \\
\hline Min & .0040253 & $-0,01098475$ & 13.81444 & $-0,10350519$ \\
\hline Max & .057159 & 0,10792559 & 16.34083 & 0,03105352 \\
\hline Standard- deviation & .0094237 & 0,00182124 & .598367 & 0,0027275 \\
\hline Observations & 190 & 190 & 190 & 190 \\
\hline
\end{tabular}

According to the table above the variable "EBTP" is $2.33 \%$ on average with a minimum of $0.40 \%$ and a maximum of $5.71 \%$, the standard deviation is $0.94 \%$. The mean of the variable "CAR is $10.11 \%$ with a minimum of $-1.098 \%$ and a maximum of $10.79 \%$. These results indicate that the banks in our sample are relatively well capitalized over the period 2001-2019 (the minimum regulatory capital required is $8 \%$ ). The standard deviation is $0.18 \%$ indicating a very low volatility of this variable in our sample.

Regarding the control variables, the mean of the variable "LASSET" is 15.18. with a minimum of 13.81 and a maximum of 16.34. Finally, the variable "ROA" shows an average of $0.86 \%$, a minimum of $-10.35 \%$, a maximum of $3.10 \%$ and a standard deviation of $0.27 \%$.

B/ Results of the multivariate regression of the second model (2001-2019):

The results of the regression carried out on our sample of 10 Tunisian commercial banks during the period from 2001 to 2019 (190 observations) are presented in Table 5.

Table 5. Model regression results during the period 2001-2019

\begin{tabular}{ccccccc}
\hline Variable & Coefficient. & Std. Err & $\mathrm{z}$ & $\mathrm{P}>\mid \mathrm{z}$ & \multicolumn{2}{c}{$[95 \%$ Conf. Interval] } \\
\hline EBTP & -.0462959 & .011859 & -3.90 & $0.000 * * *$ & -.0695391 & -.0230526 \\
CAR & .0015785 & .0052811 & 0.30 & 0.765 & -.0087723 & .0119293 \\
ROA & -.0004362 & .0002072 & -2.11 & $0.035^{* *}$ & -.0008422 & -.0000302 \\
LASSET & .0115764 & .0188907 & 0.61 & 0.540 & -.0254488 & .0486015 \\
Constante & .0108061 & .0030976 & 3.49 & 0.000 & .0047349 & .0168773 \\
\hline
\end{tabular}

***: significativité au seuil 1\%, ** significativité au seuil de $5 \%$ et * significativité au seuil $10 \%$

In view of the table above, it turns out that the coefficient of the variable EBTP becomes negative and significant at the $1 \%$ threshold on abnormal provisions during the period following the introduction of the law (2001-2019).

This negative association suggests that banks with pre-managed earnings tended to report lower (larger) abnormal provisions, thus further increasing (decreasing) earnings using ALLP. This result corroborates that of Kwak et al. (2009). However, our result is contradictory with the results found by Kanagaretnam et al (2010) and Zgarni and Fedhila (2019). 
By comparing the results of the estimation before the introduction of this law and after its introduction, it can be concluded that the introduction of the law 2001-65 relating to credit institutions has increased earnings management. Indeed, before the introduction of the said law, we found no significate relation between earnings management and abnormal provisions. This result thus contradicts the predictions of agency theory postulating that governance mechanisms reduce earnings management problems.

As for the coefficient of the CAR capital ratio, it turns out to be insignificant. This result coincides with that found by Kim and Kross (1998). But, our results are not consistent with those found by Kanagaretnam et al. (2004) and Kwak et al. (2009) and Zgarni and Fedhila (2019).

By comparing the results of the estimation before the introduction of this law and after its introduction, we can conclude that the introduction of the law 2001-65 on credit institutions limited discretionary practices through capital management. Indeed, before the introduction of the said law, we found that the Tunisian banks in our sample manage their capital ratio through abnormal provisions. This finding confirms the postulates of governance theory as to the importance of governance mechanisms, in particular the regulations, in controlling and limiting managerial opportunism and reducing information asymmetry.

By way of summary, and unlike the period preceding the promulgation of Law 2001-65, where we found that the managers of the Tunisian banks being the subject of our sample resort more to capital management than to earnings management, all of our results allow us to admit the increasing earnings management to the detriment of capital management in the discretionary practices of Tunisian banks after the introduction of the 2001 law -65 . These results can be explained by the crucial role played by this law imposing more rigorous control and more rigid and severe sanctions, in particular with regard to capital management. This state of affairs in turn explains the newly observed recourse to earnings management, given that the managers, who are by nature opportunistic according to the agency's theory, and who are subject to a stricter controls following the entry into force of this law, are diverted to earnings management where they have greater room for maneuver.

\section{Conclusion}

The entry into force of the 2001-65 law relating to Tunisian credit institutions seeks to achieve greater transparency of information by strengthening rules of good governance in order to constrain the earnings management in Tunisian banks.

In this research work, with the objective of validating the moderating effect of this Law 2001-65 relating to credit institutions on discretionary practices, we have shown first of all that Tunisian commercial banks only practice capital management before the introduction of Law 2001-65 relating to credit institutions without resorting to earnings management. Following a comparative study of discretionary practices before the introduction of this law and after its introduction, on a sample of the principal Tunisian banks we have surprisingly shown an accentuation of this discretionary behavior via loan loss provisions during the period following the entry into force of this law (2001-2019). However, the results of the survey allow us to admit the crucial role played by this law in limiting discretionary for capital management purposes compared to the period preceding the promulgation of this law (1990-2000).

In conclusion, it turns out that this law 2001-65 did not fully play its disciplinary role in matters of accounting manipulations. Indeed, if it has succeeded in limiting capital management practices, it would necessarily hide basically some possible shortcomings that have prevented it from carrying out strict control over earnings management.

However, like all research, this study is not without its limitations. In fact, Law 2001-65 is not the only law in force in Tunisia to improve the control of opportunistic behavior by managers in banks (financial security law 2005-96, law 2016-48 relating to Tunisian credit institutions). Other research may focus on taking into account the legislative texts which follow the introduction of Law 2001-65 in order to test their possible disciplinary effects on the discretionary behavior of managers in Tunisian banks. It would also probably be interesting to conduct a comparative analysis aimed at studying the evolution of legislative texts in various countries (emerging and / or developed) for limiting the discretionary practices of bank manager.

\section{References}

Abou El Sood, H. (2012). Loan loss provisioning and income smoothing in US banks pre andpost the financial crisis. International Review of Financial Analysis, 25(C), 64-72. https://doi.org/10.1016/j.irfa.2012.06.007

Ahmed, A., Takeda, C., \& Thomas, S. (1999). Bank loan loss provisions: A reexamination of capital management, earnings management, and signaling effects. Journal of Accounting and Economics, 28(1), 1-25. https://doi.org/10.1016/S0165-4101(99)00017-8 
Beatty, A., Chamberlain, S., \& Magliolo, J. (1995). Managing financial reports of commercialbanks: The influence of taxes, regulatory capital, and earnings. Journal of Accounting Research, 33, 231-261. https://doi.org/10.2307/2491487

Cohen, J., Krishnamoorthy, G., \& Wright, A. (2010). Corporate governance in the post-Sarbanes-Oxley era: Auditors' experiences. Contemporary Accounting Research, 27(3), 751-786. https://doi.org/10.1111/j.1911-3846.2010.01026.x

DeZoort, F. T., Hermanson, D. R., \& Houston, R. W. (2008). Audit committee member support for proposed audit adjustments: Pre-SOX versus postSOX judgments. Auditing: A Journal of Practice and Theory, 27(1), 85-104. https://doi.org/10.2308/aud.2008.27.1.85

Fernando, W. D. I. \& Ekanayake, E. M. N. N. (2015). Do Commercial Banks Use Loan Loss Provisions to Smooth Their Income? Empirical Evidence from Sri Lankan Commercial Banks. Journal of Finance and Bank Management, 167-179. https://doi.org/10.15640/jfbm.v3n1a15

Kanagaretnam K. (2004). Earnings Management to Reduce Earnings Variability: Evidence from Bank Loan Loss Provisions. Review of Accounting and Finance, 3(1), 128-148. https://doi.org/10.1108/eb043399/full/html

Kanagaretnam, K., Lim, C. Y., \& Lobo, G. J. (2010). Auditor reputation and earnings management: International evidence from the banking industry. Journal of Banking \& Finance, 34(10), 2318-2327. https://doi.org/10.1016/j.jbankfin.2010.02.020

Kim, M. S., \& Kross, W. (1998). The impact of the 1989 change in bank capital standards on loan loss provisions

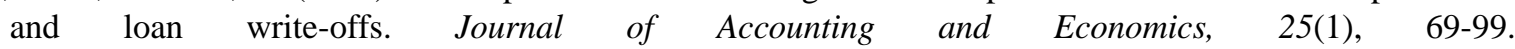
https://doi.org/10.1016/S0165-4101(98)00015-9

Kwak, W., Lee, H.-Y., \& Eldridge, S. W. (2009). Earnings Management by Japanese Bank Managers Using Discretionary Loan Loss Provisions. Review of Pacific Basin Financial Markets and Policies, 12(1), 1-26. https://doi.org/10.1142/S0219091509001526

Leventis, S., Dimitropoulos, P. E., \& Anandarajan, A. (2001). Loan Loss Provisions, Earnings Management and Capital Management under IFRS: The Case of EU Commercial Banks. J Financ Serv Res., 40, 103-122. https://doi.org/10.1007/s10693-010-00"96-1

Lobo, G. J., \& Yang, D. H. (2001). Bank managers' heterogeneous decisions on discretionary loan loss provisions. Review of Quantitative Finance and Accounting, 16, 223-250. https://doi.org/10.1023/A:1011284303517

Taktak Boulila, N., \& Mbarki, I. (2014). Board characteristics, external auditing quality and earnings management: Evidence from the Tunisian banks. Journal of Accounting in Emerging Economies, 4(1), 79-96. https://doi.org/10.1108/JAEE-10-2011-0046

Zgarni, A., \& Fedhila, H. (2019). Discretionary Loan Loss Provisions, Earnings Management and Capital Management in Banks. Wseas Transactions on Business and Economics, 16. Retrieved from https://www.wseas.org/multimedia/journals/economics/2019/a885107-770.php

\section{Copyrights}

Copyright for this article is retained by the author(s), with first publication rights granted to the journal.

This is an open-access article distributed under the terms and conditions of the Creative Commons Attribution license (http://creativecommons.org/licenses/by/4.0/). 